\title{
Lichen diversity of Padder Valley Kishtwar (J\&K), India
}

\section{Sachin Sharma}

Department of Environmental Sciences, University of Jammu, Jammu-180006 (J\&K), India

Anil K. Raina*

Department of Environmental Sciences, University of Jammu, Jammu-180006 (J\&K), India

\section{K. Upreti}

Lichenology Laboratory, Biodiversity and Conservation Division, NBRI (CSIR), Lucknow (Uttar Pradesh), India

${ }^{*}$ Corresponding author. E-mail: anilkraina@yahoo.com

\section{Abstract}

Lichens are one of the most successful group of organisms and form an important aspect of biodiversity of any region. But still lichens are under explored in most of regions. The present work has been carried out in Padder Valley, Kishtwar, Jammu and Kashmir (J\&K). A thorough survey of the lichen diversity from all the possible habitats was conducted in the study area which indicated the presence of 110 species belonging to 54 genera and 23 families. Parmiliaceae has been recorded as the largest family (16 genera, 27 species) and is followed by Physciaceae ( 8 genera, 14 species). Four families have been observed to be monotypic. Lecanora has been recorded as dominant genera with 7 species followed by Peltigera with 5 species. Corticolous was most preferred substratum exhibited by 61 species while foliose was the most dominant type of growth form represented by 52 species. The study has added 94 lichen taxa as new records for district Kishtwar and is first of its kind in Padder Valley, J\&K.

Keywords: Corticolous, Foliose, Kishtwar, Lichen diversity, Padder valley, Parmiliaceae

\section{INRODUCTION}

Lichens, a unique symbiotic association between the algae and fungus (and yeast, Spribille, et al., 2016), are cosmopolitan in their distribution and grow on variety of different substratum which includes trees, rocks, soil and various man-made structures. The growth of lichens on different substrata depend upon the various factors like regional climatic factors (average rainfall and average temperature), microclimatic factors (light availability, moisture, temperature, etc) and substrate characteristics like rock composition, bark type, $\mathrm{pH}$, rough surface and moisture retention ability (Hawksworth and Rose,1976; James et al.,1977; Hawksworth and Hill, 1984; Wolseley and Aguirre -Hudson,1997; Mulligan, 2009).

Singh and Sinha (2010) have reported the presence of 2532 lichen species belonging to 324 genera and 78 families in India. However in a megabiodiversity nation like India with varied climatic and topographic features, the reported number of lichen species is not sufficient and hence requires rigorous exploration of newer areas. In the state of Jammu and Kashmir a total of 356 species of lichens belonging to 35 families and 91 genera

\section{Article Info}

DOI:10.31018/jans.v11i2.2119

Received: May 1, 2019

Revised: June 3, 2019

Accepted: June 8, 2019

\section{How to Cite}

Sharma S. et al. (2019).

Lichen diversity of Padder Valley Kishtwar (J\&K), India. Journal of Applied and Natural Science, 11 (2): 511 - 515 https:// doi.org/10.31018/ jans.v11i2.2119 
Table 1. Lichen species collected from the study area, their families, substratum and growth forms.

\begin{tabular}{|c|c|c|c|c|}
\hline S.N. & Lichen Species & Family & Substratum & Growth Form \\
\hline 1. & *Acarospora fusca B.de Lesd. & Acarosporaceae & Crustose & Saxicolous \\
\hline 2. & ${ }^{*}$ Acarospora sp & Acarosporaceae & Crustose & Saxicolous \\
\hline 3. & ${ }^{*}$ Allocetraria $s p$ & Parmeliaceae & Foliose & Corticolous \\
\hline 4. & *Anaptychia kaspica Gyel. & Physciaceae & Foliose & Corticolous \\
\hline 5. & Aspicilia calcarea (L.) Mudd. & Megasporaceae & Crustose & Saxicolous \\
\hline 6. & ${ }^{*}$ Aspicilia contorta (Hoffm) Krempelh. & Megasporaceae & Crustose & Saxicolous \\
\hline 7. & ${ }^{*}$ Buellia disciformis (Fr.) Mudd. & Caliciaceae & Crustose & Saxicolous \\
\hline 8. & ${ }^{*}$ Buellia sp & Caliciaceae & Crustose & Saxicolous \\
\hline 9. & ${ }^{*}$ Caloplaca saxicola (Hoffm) Nordin & Teloschistaceae. & Crustose & Saxicolous \\
\hline 10. & ${ }^{*}$ Caloplaca sp & Teloschistaceae. & Crustose & Saxicolous \\
\hline 11. & Caloplaca subsoluta (Nyl.) Zahlbr. & Teloschistaceae. & Crustose & Saxicolous \\
\hline 12. & Candelaria concolor (Dicks.)B Stein & Candelariaceae & Crustose & Corticolous \\
\hline 13. & ${ }^{*}$ Candelariella vittellina (Hoffm.) Mull. Arg. & Candelariaceae & Crustose & Saxicolous \\
\hline 14. & $\begin{array}{l}{ }^{*} \text { Cetrelia cetrarioides } \\
\text { ( Delise ex Duby) Club \& Club }\end{array}$ & Parmeliaceae & Foliose & Corticolous \\
\hline 15. & ${ }^{*}$ Cladonia chlorophaea (Florke) Spring & Cladoniaceae & Fruticose & Lignicolous \\
\hline 16. & ${ }^{*}$ Cladonia corniculata Ahti \&Kashi. & Cladoniaceae & Fruticose & Lignicolous \\
\hline 17. & ${ }^{*}$ Cladonia fimbriata (L.) Fr. & Cladoniaceae & Fruticose & Corticolous \\
\hline 18. & ${ }^{*}$ Cladonia pyxidata (L.) Hoffm. & Cladoniaceae & Fruticose & Corticolous \\
\hline 19. & ${ }^{*}$ Cryptothecia sp & Arthoniaceae & Crustose & Saxicolous \\
\hline 20. & ${ }^{*}$ Collema sp & Collemataceae & Foliose & Saxicolous \\
\hline 21. & ${ }^{*}$ Dermatocarpon miniatum (L.)Mann. & Verrucariaceae & Foliose & Saxicolous \\
\hline 22. & ${ }^{*}$ Dermatocarpon vellerum Zschacke & Verrucariaceae & Foliose & Saxicolous \\
\hline 23. & ${ }^{*}$ Diploschistes scruposus (Schreb.)Norman & $\begin{array}{l}\text { Thelotrema- } \\
\text { taceae }\end{array}$ & Crustose & Saxicolous \\
\hline 24. & ${ }^{*}$ Diploschistes sp & $\begin{array}{l}\text { Thelotrema- } \\
\text { taceae }\end{array}$ & Crustose & Saxicolous \\
\hline 25. & ${ }^{*}$ Dirinaria aegialita (Afz. in Ach.) Moore & Caliciaceae & Foliose & Corticolous \\
\hline 26. & ${ }^{*}$ Endocarpon subrosettum A. Singh \& Upreti & Verrucariaceae & Crustose & Saxicolous \\
\hline 27. & ${ }^{\star}$ Evernia diverticata (L.) Ach & Parmeliaceae & Fruticose & Corticolous \\
\hline 28. & ${ }^{\star}$ Evernia prunastri (L.) Ach & Parmeliaceae & Fruticose & Corticolous \\
\hline 29. & ${ }^{*}$ Everniastrum cirrhatum (Fr.) Hale ex Sipman & Parmeliaceae & Fruticose & Corticolous \\
\hline 30. & Flavoparmelia caperata (L.) Hale & Parmeliaceae & Foliose & Corticolous \\
\hline 31. & ${ }^{*}$ Flavopunctalia soredica (Nyl.) Hale & Parmeliaceae & Foliose & Corticolous \\
\hline 32. & Flavopunctelia flaventior (Stirt.) Hale & Parmeliaceae & Foliose & Corticolous \\
\hline 33. & ${ }^{*}$ Heterodermia japonica (Sato) Swinse \& Krog. & Physciaceae & Foliose & Corticolous \\
\hline 34. & ${ }^{*}$ Heterodermia $s p$ & Physciaceae & Foliose & Corticolous \\
\hline 35. & $\begin{array}{l}\text { *Hyperphyscia adglutinata (Flörke) Mayrhofer \& } \\
\text { Poelt }\end{array}$ & Physciaceae & Foliose & Corticolous \\
\hline 36. & *Hypogymnia vittata (Ach.) Nyl. & Parmeliaceae & Foliose & Corticolous \\
\hline 37. & *Lecanora achroa Nyl. & Lecanoraceae & Crustose & Corticolous \\
\hline 38. & ${ }^{*}$ Lecanora campestris (Schaer.) Hue & Lecanoraceae & Crustose & Saxicolous \\
\hline 39. & *Lecanora frustulosa Dicks.) Ach. & Lecanoraceae & Crustose & Saxicolous \\
\hline 40. & *Lecanora indica Zahlbr. & Lecanoraceae & Crustose & Saxicolous \\
\hline 41. & *Lecanora muralis (Schreb.) Rabenh. & Lecanoraceae & Crustose & Saxicolous \\
\hline 42. & *Lecanora perplexa Broda. & Lecanoraceae & Crustose & Corticolous \\
\hline 43. & *Lecanora subrugosa Nyl. & Lecanoraceae & Crustose & Corticolous \\
\hline 44. & *Lecanora sp & Lecanoraceae & Crustose & Saxicolous \\
\hline 45. & *Lecidella euphorea (Florke) Hertel & Lecanoraceae & Crustose & Corticolous \\
\hline 46. & * Lepraria lobificans Nyl. & Lichen imferfecti & Leprose & Terricolous \\
\hline 47. & ${ }^{*}$ Lepraria sp & Lichen imferfecti & Leprose & Terricolous \\
\hline 48. & ${ }^{*}$ Leptogium denticulatum Tuck & Collemataceae & Foliose & Saxicolous \\
\hline 49. & ${ }^{*}$ Leptogium furfuraceum (Harm.)Sierk & Collemataceae & Foliose & Corticolous \\
\hline 50. & *Leptogium saturninum (Dicks)Nyl. & Collemataceae & Foliose & Corticolous \\
\hline 51. & ${ }^{*}$ Lobothallina praesorediosa (Nyl.) Hafellner & Megasporaceae & Crustose & Saxicolous \\
\hline 52. & ${ }^{*}$ Lobothallium $s p$ & Megasporaceae & Crustose & Saxicolous \\
\hline \multirow[t]{2}{*}{53.} & Melanelia elegntula (Zahlbr.) Essl. & Parmeliaceae & Foliose & Corticolous \\
\hline & & & & Contd... \\
\hline
\end{tabular}


Sharma S. et al. / J. Appl. \& Nat. Sci. 11(2): 511 - 515 (2019)

\begin{tabular}{|c|c|c|c|c|}
\hline 54. & ${ }^{*}$ Melanelixia fuliginosa(Fr. Ex Duby) Blanco \&al. & Parmeliaceae & Foliose & Corticolous \\
\hline 55. & *Melanelixia glabra (Schaer.)Blanco \&al. & Parmeliaceae & Foliose & Corticolous \\
\hline 56. & *Melanelixia subargentifera (Nyl.)Blanco \& al. & Parmeliaceae & Foliose & Corticolous \\
\hline 57. & ${ }^{*}$ Mycobilimbia sp & Lecideaceae & Crustose & Saxicolous \\
\hline 58. & *Parmelia maculalis Taylor & Parmeliaceae & Foliose & Corticolous \\
\hline 59. & ${ }^{*}$ Parmelia sulcata Taylor & Parmeliaceae & Foliose & Corticolous \\
\hline 60. & Parmelina pastillifera (Harmand) Hale & Parmeliaceae & Foliose & Corticolous \\
\hline 61. & ${ }^{*}$ Parmelina tiliaceae (Hoffm.) Hale & Parmeliaceae & Foliose & Corticolous \\
\hline 62. & ${ }^{*}$ Parmotrema dilatatum (Vainio)Hale & Parmeliaceae & Foliose & Corticolous \\
\hline 63. & ${ }^{*}$ Parmotrema reticulatum (Taylor) Choisy & Parmeliaceae & Foliose & Corticolous \\
\hline 64. & Parmotrema tinctorum (Nyl) & Parmeliaceae & Foliose & Corticolous \\
\hline 65. & ${ }^{*}$ Peltigera didactyla (With.) J.R. Laundon & Peltigeraceae & Foliose & Saxicolous \\
\hline 66. & ${ }^{*}$ Peltigera elisabethae Gyeln. & Peltigeraceae & Foliose & Saxicolous \\
\hline 67. & ${ }^{*}$ Peltigera horizontalis (Huds) Baumg. & Peltigeraceae & Foliose & Terricolous \\
\hline 68. & ${ }^{*}$ Peltigera polydactylon (Neck) Hoffm & Peltigeraceae & Foliose & Saxicolous \\
\hline 69. & ${ }^{*}$ Peltigera praetextata (Florke)Zopf & Peltigeraceae & Foliose & Saxicolous \\
\hline 70. & $\begin{array}{l}\text { *Pertusaria albescens var. albescens (Huds.) M. } \\
\text { Choisy \& Werner in Werner }\end{array}$ & Pertusariaceae & Crustose & Corticolous \\
\hline 71. & *Pertusaria leucosora (Nyl.) & Pertusariaceae & Crustose & Saxicolous \\
\hline 72. & “Phaeophyscia hispidula (Ach.) Essl. & Physciaceae & Foliose & Corticolous \\
\hline 73. & Phaeophyscia orbicularis (Neck.) Moberg & Physciaceae & Foliose & Corticolous \\
\hline 74. & Physcia aipolia (Ehrh. Ex Humb.) Furnr & Physciaceae & Foliose & Corticolous \\
\hline 75. & *Physcia dimidata (Arn.)Nyl. & Physciaceae & Foliose & Corticolous \\
\hline 76. & ${ }^{\star}$ Physcia dubia (Hoffm.)Lett & Physciaceae & Foliose & Corticolous \\
\hline 77. & ${ }^{*}$ Physcia stellaris (L.) Nyl. & Physciaceae & Foliose & Corticolous \\
\hline 78. & ${ }^{*}$ Physconia distorta (With.) J.R. Laundon & Physciaceae & Foliose & Corticolous \\
\hline 79. & ${ }^{*}$ Physconia perisidiosa (Erichsen)Moberg & Physciaceae & Foliose & Corticolous \\
\hline 80. & $\begin{array}{l}\text { *Porpidia crustulata (Ach)Hertal and Knoph in } \\
\text { Hertal }\end{array}$ & Porpidiaceae & Crustose & Saxicolous \\
\hline 81. & $\begin{array}{l}\text { *Porpidia hydrophila (Fr.) Hertal and Knoph in } \\
\text { Hertal }\end{array}$ & Porpidiaceae & tose & lous \\
\hline 82. & *Porpidia macrocarpa (DC.) Hertel and Schwab. & Porpidiaceae & Crustose & Saxicolous \\
\hline 83. & ${ }^{*}$ Pseudoevernia furfuracea (L.) Zopf. & Parmeliaceae & Fruticose & Corticolous \\
\hline 84. & ${ }^{*}$ Psora decipiens (Hedwing) Hoffm. & Psoraceae & Foliose & Terricolous \\
\hline 85. & ${ }^{*}$ Punctalia borreri (Sm.)Krog & Parmeliaceae & Fruticose & Corticolous \\
\hline 86. & ${ }^{*}$ Punctalia rudecta (Ach.) Krog. & Parmeliaceae & Foliose & Corticolous \\
\hline 87. & Punctalia subrudecta (Nyl.) krog & Parmeliaceae & Foliose & Corticolous \\
\hline 88. & ${ }^{*}$ Ramalina hossei var. Hossei Vain. & Ramalinaceae & Fruticose & Corticolous \\
\hline 89. & *Ramalina pollinaria (Westr.) Ach. & Ramalinaceae & Fruticose & Corticolous \\
\hline 90. & Ramalina sinensis Jatta & Ramalinaceae. & Fruticose & Corticolous \\
\hline 91. & Rhizocarpon disporum (Naeg ex Hepp) Müll. Arg. & Rhizocarpaceae & Crustose & Saxicolous \\
\hline 92. & ${ }^{*}$ Rhizocarpon distinctum Th. Fr. & Rhizocarpaceae & Crustose & Saxicolous \\
\hline 93. & ${ }^{*}$ Rhizocarpon geographicum (L.) DC. & Rhizocarpaceae & Crustose & Saxicolous \\
\hline 94. & ${ }^{*}$ Rhizoplaca chrysoleuca (Sm.) Zopf & Lecanoraceae. & Crustose & Saxicolous \\
\hline 95. & ${ }^{*}$ Rinodina badiella (Nyl.) Th. Fr. & Physciaceae & Crustose & Saxicolous \\
\hline 96. & ${ }^{*}$ Rinodina $s p$ & Physciaceae & Crustose & Saxicolous \\
\hline 97. & *Stereocaulon foliolosum Nyl. & Stereocaulaceae & Fruticose & Corticolous \\
\hline 98. & *Usnea aciculifera Vainio & Usneaceae & Fruticose & Corticolous \\
\hline 99. & *Usnea longissima Ach. & Usneaceae & Fruticose & Corticolous \\
\hline 100. & *Usnea subfloridana Stirt. & Usneaceae & Fruticose & Corticolous \\
\hline 101. & *Usnea undulate Stirton & Usneaceae & Fruticose & Corticolous \\
\hline 102. & ${ }^{*}$ Verrucaria aethiobola Wahlb. in Ach. & Verrucariaceae & Crustose & Saxicolous \\
\hline 103. & $\begin{array}{l}\text { *Vulpicida pinastri (Scop.) J.E. Mattsson \& M. J. } \\
\text { Lai }\end{array}$ & Parmeliaceae & Foliose & Corticolous \\
\hline 104. & $\begin{array}{l}\text { *Xanthomendoza fallax (Hepp ex Arn.) Sochting, } \\
\text { Kärnefelt \& S.Y. Kondr. }\end{array}$ & Teloschistaceae & Foliose & Corticolous \\
\hline 105. & $\begin{array}{l}\text { Xanthomendoza fulva (Hoffm.) Sochting, Karne- } \\
\text { felt \& S.Y. Kondr. }\end{array}$ & Teloschistaceae & Foliose & Corticolous \\
\hline 106. & ${ }^{*}$ Xanthoparmelia mexicana (Gyelnik) Hale & Parmeliaceae & Foliose & Saxicolous \\
\hline 107. & $\begin{array}{l}\text { *Xanthoparmelia stenophylla (Ach.) Ahti \& D. } \\
\text { Hawksw. }\end{array}$ & Parmeliaceae & Foliose & Saxicolous \\
\hline 108 & Xanthoria candelaria (L.) Th. Fr. & Teloschistaceae & Foliose & Corticolous \\
\hline 109 & Xanthoria elegans (Link) Th. Fr. & Teloschistaceae & Foliose & Corticolous \\
\hline 110. & Xanthoria parietina (L.) Th. Fr. & Teloschistaceae & Foliose & Corticolous \\
\hline
\end{tabular}

*New record for the district Kishtwar, J\&K. 
Sharma S. et al. / J. Appl. \& Nat. Sci. 11(2): 511 - 515 (2019)

Table 2. Comparison of dominant lichen families of the study area with the adjoining areas.

\begin{tabular}{|c|c|c|c|c|c|}
\hline $\begin{array}{l}\text { S. } \\
\text { N. }\end{array}$ & $\begin{array}{ll}\text { Padder } & \text { Valley } \\
\text { (Author) } & \end{array}$ & $\begin{array}{l}\text { J\&K } \\
\text { (Sheikh, 2009) }\end{array}$ & $\begin{array}{l}\text { Ladakh } \\
\text { (Kumar et al., 2012) }\end{array}$ & $\begin{array}{l}\text { J\&K (Goni et } \\
\text { al., 2015) }\end{array}$ & $\begin{array}{l}\text { Kumaon Himalayas } \\
\text { (Mishra and Upreti, } \\
\text { 2016) }\end{array}$ \\
\hline 1. & Parmeliaceae & Parmeliaceae & Physciaceae & Parmeliaceae & Parmeliaceae \\
\hline 2. & Physciaceae & Physciaceae & raceae & Physciaceae & Physciaceae \\
\hline 3. & Lecanoraceae & Teloschistaceae & Lecanoraceae & Lecanoraceae & Collemataceae \\
\hline 4. & Teloschistaceae & Lecanoraceae & Megasporaceae & Teloschistaceae & Lobariaceae \\
\hline 5. & Peltigeraceae & Verrucariaceae & Parmeliaceae & Cladoniaceae & Peltigeraceae \\
\hline
\end{tabular}

Table 3. Comparison of substrate preferences and growth form of lichens of the study area with the adjoining areas.

\begin{tabular}{|c|c|c|c|c|c|c|}
\hline $\begin{array}{l}\text { S. } \\
\text { N. }\end{array}$ & & $\begin{array}{l}\text { J\&K } \\
\text { (Sheikh, } \\
\text { 2009) } \\
\end{array}$ & $\begin{array}{l}\text { Ladakh } \\
\text { (Kumar et al., } \\
\text { 2012) }\end{array}$ & 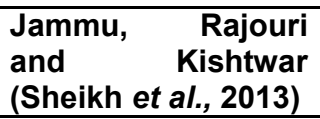 & $\begin{array}{l}\text { Kumaon Himala- } \\
\text { yas (Mishra and } \\
\text { Upreti, 2016) }\end{array}$ & $\begin{array}{l}\text { Padder } \\
\text { Valley } \\
\text { (Author) }\end{array}$ \\
\hline 1 & & Corticolous & Saxicolous & Corticolous & Corticolous & Corticolous \\
\hline & Substrate & $\begin{array}{l}\text { Saxicolous } \\
\text { Terricolous }\end{array}$ & $\begin{array}{l}\text { Terricolous } \\
\text { - }\end{array}$ & $\begin{array}{l}\text { Saxicolous } \\
\text { - }\end{array}$ & $\begin{array}{l}\text { Saxicolous } \\
\text { Terricolous }\end{array}$ & $\begin{array}{l}\text { Saxicolous } \\
\text { Terricolous }\end{array}$ \\
\hline 2 & Growth form & $\begin{array}{l}\text { Crustose } \\
\text { Foliose } \\
\text { Fruticose }\end{array}$ & $\begin{array}{l}\text { Crustose } \\
\text { Foliose } \\
\text { Fruticose }\end{array}$ & $\begin{array}{l}\text { Crustose } \\
\text { Foliose } \\
\text { Fruticose }\end{array}$ & $\begin{array}{l}\text { Foliose } \\
- \\
-\end{array}$ & $\begin{array}{l}\text { Foliose } \\
\text { Crustose } \\
\text { Fruticose }\end{array}$ \\
\hline
\end{tabular}

\section{MATERIALS AND METHODS}

Lichen samples were collected from different substrates (i.e, rocks, trees and soil) and dried in the folds of bolting paper or newspapers. Dried samples were packed in lichen herbarium packets with details of locality, date of collection, name of collector and other ecological notes. The collected lichen samples were examined and identified at Lichenology Laboratory, National Botanical Research Institute, Lucknow, Uttar Pradesh, India. Morpho-anatomical analysis was carried out using a stereomicroscope and light microscope and chemical analysis with the help of spot tests, UV light and standardized thin-layer chromatography (Elix et al., 1993). Available literature of different workers (Awasthi, 1988, 1991, 2000; Upreti, 1998; Singh and Sinha, 2010; Nayaka and Upreti, 2011; Kumar et al., 2012; Goni et al., 2015) was also consulted for identification of lichen taxa.

\section{RESULTS AND DISCUSSION}

The list of lichen species, collected and identified from all the possible substrata of Padder valley, Kishtwar, J\&K, India has been presented in table 1 along with their families, growth form and the substratum. A total of 110 lichen species belonging to 23 families and 54 genera have been recorded from the study area of these 94 lichen taxa are new records for district Kishtwar, J\&K (Table 1). Parmaliaceae has been recorded as the largest family ( 27 species) followed by Physciaceae (14 species), Teloschistaceae (8 species) and Peltigeraceae (5 species). Four families (Lecideaceae, Psoraceae, Sterocaulaceae and Arthoniaceae ) have been observed to be monotypic (represented by one species each). Comparison of first five dominant families has been carried out with the dominant families of adjoining areas (Table 2) which also revealed Parmaliaceae and Physiaceace to be the first two dominant families in the J\&K (Sheikh, 2009, Goni et al., 2015) and Kumaon Himalayas (Mishra and Upreti, 2016). However, Physiaceace has been recorded as the dominant family in Ladakh region ( Kumar et al., 2012)

Substratum preferences of the lichen species in the study area and adjoining regions has been depicted in Table 1 and 3. Perusal of the tables revealed corticolous species (61 species) to be the dominant followed by saxicolous (43 species), terricolous (4 species) and lignicolous (2 species). Corticolous lichens have also been observed as the dominant in different regions of J\&K (Sheikh, 2009), Jammu, Rajouri and Kishtwar districts of the state (Sheikh et al., 2013) and Kumaon Himalayas (Mishra and Upreti, 2016).

Lichens in Padder valley also exhibit different growth forms (Table1), of which foliose (52 species) has been observed to be the dominant growth form followed by crustose (39 species), fruticose (17 species) and leprose (2 species) growth forms. Mishra and Upreti (2016) has also reported foliose lichens to be dominant in Kumaon Himalayas. However, crustose lichens have been reported as dominant growth form in J\&K (Sheikh, 2009), Ladakh (Kumar et al., 2012) and Jammu, Rajouri and Kishtwar districts of the state (Sheikh et al., 2013).

\section{Conclusion}

The present study revealed that the study area i.e. Padder Valley, Kishtwar district of Jammu and Kashmir (J\&K) is rich in lichen diversity as it is represented by 110 species belonging to 54 genera and 23 families. Rich lichen diversity is an indicator of ecological health of any ecosystem and recording of 110 lichen species in the study area which accounts for $30.90 \%$ of the total lichen diversity of 356 lichen species from J\&K state which 
indicates the healthy ecosystem of the study area. 94 lichen species are new records for district Kishtwar of J\&K. The present study also helps to know the extent of distribution of lichens in the previously unexplored region of the state of J\&K.

\section{ACKNOWLEDGEMENTS}

The authors are thankful to Director, National Botanical Research Institute, Lucknow for providing necessary laboratory facilities.

\section{REFERENCES}

1. Awasthi D.D. (1988). A key to the macrolichens of India and Nepal. Journal of the Hattori Botanical Laboratory 65: 207-302.

2. Awasthi D.D. (1991). A key to the macrolichens of India, Nepal and Srilanka. Bibliotheca Lichenologica (Suppl.)40: 1-337.

3. Awasthi D.D. (2000). Lichenology in Indian Subcontinent. Dehradun: Bishen Singh Mahendrapal Singh.

4. Elix J.E. and Ernst-Russel K.D. (1993). A Catalogue of Standardized Thin Layer Chromatographic Data and Biosynthetic Relationships for Lichen Substances. 2nd edn. Australian National University, Canberra, Australia

5. Goni R., Raina A. K. P., Magotra Rani and Sharma Namrata. (2015). Lichen flora of Jammu and Kashmir State, India: An updated checklist. Tropical Plant Research 2(1) 64-71.

6. Hawksworth D.L. and Hill D. J. (1984) The lichen forming fungi. Blackie \& Son Limited, Glasgow.

7. Hawksworth, D.L. and Rose F. (1976). Lichens as pollution monitors. Edward Arnold Publishers, London.

8. James P.W., Hawksworth D.L. and Rose F. (1977). Lichen communities in the British Isles: a preliminary conspectus. Lichen Ecology (eds. M.R.D. Seaward), Academic Press, London.

9. Kumar, J., Khare, R., Rai, H., Upreti, D. K., Tayade, A., Hota1, S. , Chaurasia1, O. P. and Srivastava, R. B. (2012). Diversity of lichens along altitudinal and land use gradients in the Trans Himalayan cold desert of Ladakh. Nature and Science, 10 (4).

10.Kumar J, Rai H, Khare R, Upreti DK, Dhar P, Tayade AB, Chaurasia OP \& Srivastava RB (2014). Elevational controls of lichen communities in Zanskar valley, Ladakh, a Trans Himalayan cold desert. Tropical
Plant Research 1(2): 48-54.

11.Mishra, G. K. and Upreti, D. K. (2016). Diversity and distribution of macro-lichen in Kumaun Himalaya, Uttarakhand. International Journal of Advanced Research.4 (2) pp 912-925.

12.Mulligan, L. (2009). An assessment of epiphytic lichens, lichen diversity and environmental quality in the semi-natural woodlands of Knocksink Wood Nature Reserve, Enniskerry, County Wicklow. PhD thesis, Dublin Institute of Technology, Dublin, Ireland.

13. Nayaka, S. and Upreti, D.K. (2011). An Inventory of Lichens in Uttar Pradesh through Bibliographic Compilation. National Conference on Earth's Living Treasure, Uttar Pradesh State Biodiversity Board.

14.Rahim, A., Raina, A.K. and Hussan, A. (2014) Lichen diversity of Kargil town and its adjoining areas, J\&K, International Journal of Current Research 5(14): $1-4$.

15.Sheikh, M.A., Upreti, D.K. and Raina, A.K. (2006) Lichen Diversity in Jammu and Kashmir, India. Geophytology 36(1\&2): 69-85.

16.Sheikh, M.A., Raina, A.K. and Upreti, D.K. (2009). Lichen Flora of Surinsar-Mansar Wildlife Sanctuary, Jammu and Kashmir. Journal of Applied and Natural Science 1(1): 79-81

17.Sheikh, M.A., Raina, A.K. and Hussan, A. (2013). A preliminary observation of lichen flora in three districts of Jammu \& Kashmir. International Journal of Current Research 5(4): 966-68.

18.Singh, K.P. and Sinha, G.P. (2010). Indian lichens: an annotated checklist. Govt. of India, Botanical Survey of India. Ministry of Environment and Forest, India, pp 571.

19.Spribille' T., Tuovinen, V., Resl, P., Vanderpool, D., Wolinski, H., Catherine Aime M., Schneider, K., Stabentheiner, E., Toome-Heller,M., Thor, G., Mayrhofer, H., Johannesson, $H$. and McCutcheon J. P. (2016) Basidiomycete yeasts in the cortex of ascomycete macrolichens. Science, 353 (6298): 488-492. DOI: 10.1126/science.aaf8287

20.Upreti, D.K. (1998). Diversity of Lichens in India, In Perspectives in Environment (eds.Agarwal S.K., Kaushik J.P., Kaul K.K., and Jain A.K.), APH Publishing Corporation, New Delhi,pp71-79.

21.Wolseley, P. and Aguirre-Hudson, B. (1997). Lichens of tropical forests in Thailand: A field key to characteristic epiphytic species in northern Thailand. Department of Botany, National History Museum, London. Pp. 1-9. 